\title{
Climatic factors defining the height growth curve of forest species
}

\author{
Elvis Felipe Elli ${ }^{(1)}$, \\ Braulio Otomar Caron ${ }^{(1)}$, \\ Alexandre Behling ${ }^{(2)}$, \\ Elder Eloy ${ }^{(1)}$, \\ Velci Queiróz De Souza(1), \\ Felipe Schwerz ${ }^{(1)}$, \\ John Robert Stolzle ${ }^{(1)}$
}

\begin{abstract}
The aim of this study was to modify several existing biological models by including several predictive variables that take into account the effect of climatic factors on tree height growth. Tree height was measured from 2007 to 2014 on 18 trees for each of the following species: Eucalyptus urophylla $\times$ Eucalyptus grandis, Parapiptadenia rigida, Peltophorum dubium, Mimosa scabrella and Schizolobium parahybae. Different existing nonlinear models were fitted to the observed data, and the best fitting models were selected. The inclusion of climatic variables into the selected models (mainly minimum temperature and rainfall) improved their predictions of tree height growth with age, and provided more accurate estimates than those obtained by traditional nonlinear models. Simulations were carried out to explore the variation of tree height growth under different minimum temperature and precipitation regimes. The effects of frost and rainfall variation on height growth curves and their consequences for forest management are discussed.
\end{abstract}

Keywords: Von Bertalanffy-Richards' Model, Mean Minimum Temperature, Rainfall, Frost

gression models in biology is their use in modeling tree growth curves by fitting nonlinear functions.

Biological growth models usually present the organism size or weight as the dependent variable, and the organism age as predictor, without taking into account climatic factors. In regions where trees are subjected to harsh winters with absolute minimum temperatures below zero and frost occurrence, tree species sensitive to cold may incur damages to apical buds. Damage caused by winter conditions can potentially limit the growth of the upper third of the trees. To date, these and other variations in the growth curve due to climatic factors are not explained by biological models in the literature.

Evidence of the importance of using climatic factors in forest modeling to explain the responses of tree species have been documented in several reports (Subedi \& Sharma 2013, Prior \& Bowman 2014, Rais et al. 2014, Trouvé et al. 2015). According to

$\square$ (1) Federal University of Santa Maria, Frederico Westphalen Campus, Graduate Program in Agronomy - Agriculture and Environment. Linha Sete de Setembro n/a, Highway 386 km 40, CEP 98400-000, Frederico Westphalen, Rio Grande do Sul State (Brazil); (2) Federal University of Paraná, Graduate Program in Forest Engineering. Av. Pref. Lothário Meissner, 900, Jardim Botânico, Campus III, CEP 80210-160, Curitiba, Paraná (Brazil)

@ Elvis Felipe Elli (elvisfelipeelli@yahoo.com)

Received: Aug 03, 2016 - Accepted: Feb 19, 2017

Citation: Elli EF, Caron BO, Behling A, Eloy E, Queiróz De Souza V, Schwerz F, Stolzle JR (2017). Climatic factors defining the height growth curve of forest species. iForest 10: 547553. - doi: 10.3832/ifor2189-010 [online 2017-05-05]

several authors (Hunter \& Gibson 1984, Woollons et al. 1997, Snowdon et al. 1998, 1999), the predictive power of empirical models used to describe growth data can be improved by the incorporation of indices which account for climatic factors.

In this study we tested the hypothesis that climatic factors, along with plant age, can be profitably used to define height growth curves of forest tree species. To this purpose, we modified several existing biological models by adding predictive variables that take into account the effect of climatic factors on tree height growth.

\section{Material and methods}

\section{Data source}

The study was conducted in the city of Frederico Westphalen, Rio Grande do Sul, Brazil, located at $27^{\circ} 22^{\prime} \mathrm{S}, 53^{\circ} 25^{\prime} \mathrm{W}$ at the altitude of $480 \mathrm{~m}$ a.s.l. (Fig. 1). The following tree species were used: Eucalyptus urophylla S.T. Blake $\times$ Eucalyptus grandis Hill ex Maiden, Mimosa scabrella Benth., Parapiptadenia rigida, Peltophorum dubium (Spr.) Taubert and Schizolobium parahybae (Vell.) Blake.

The experiment was established in September 2007, through the manual planting of seedlings after ploughing and harrowing the area. The experimental design was a randomized complete block design and the variables measured were the tree species, tree age and height, with three replicates for each treatment.

The determination of tree height began in March 2008, at the beginning of the autumn season, by selecting 18 trees of each species for the analysis. Since then, quarterly evaluations were carried out on the selected trees at the beginning of each sea- 


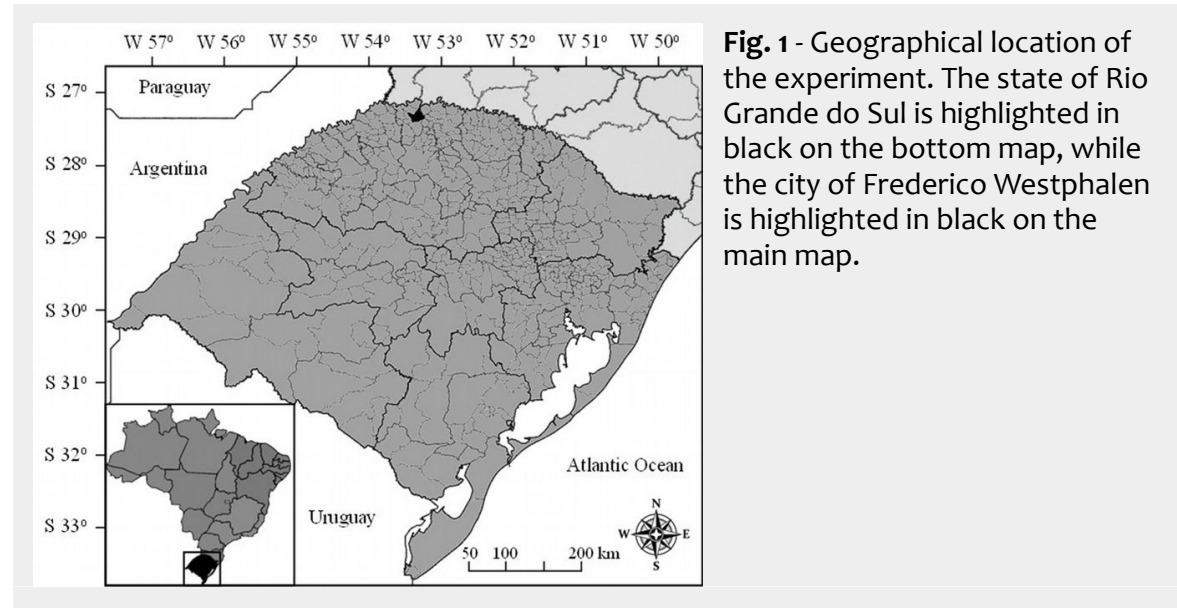

son, until spring 2014. Tree height was measured from the ground level to the top leaf axils using a measuring tape until they reached $2.0 \mathrm{~m}$, and using a Vertex III Hypsometer thereafter.

\section{Height modeling}

Seven non-linear models (Schumacher, von Bertalanffy-Richards, Clutter-Jones, Prodan, Mitscherlich, Gompertz, and Bailey

with 4 parameters) were tested in order to estimate the tree height as a function of age, as described in Tab. S1 (Supplementary material).

Model performances were evaluated by the following criteria: coefficient of variation (CV, \%), standard error (SE, $\mathrm{m}$ ), graphic analysis of residuals (\%), and the Pearson's correlation coefficient between observed values and model predictions. For the esti-

Tab. 1 - Fit statistics and coefficients obtained by fitting seven nonlinear models to describe the height growth of five tree species. The models used (see also Tab. S1 in Supplementary material) were: (Sch) Schumacher; (vB-R) von Bertalanffy-Richards; (C-J) Clutter-Jones; (Pro) Prodan; (Mit) Mitscherlich; (Gom) Gompertz; (B4P) Bailey 4P. (CV): coefficient of variation; (SE): standard error.

\begin{tabular}{|c|c|c|c|c|c|c|c|}
\hline \multirow{2}{*}{ Species } & \multirow{2}{*}{ Model } & \multicolumn{4}{|c|}{ Coefficients } & \multirow{2}{*}{$\begin{array}{l}\mathrm{CV} \\
\text { (\%) }\end{array}$} & \multirow{2}{*}{$\begin{array}{l}\mathrm{SE} \\
(\mathrm{m})\end{array}$} \\
\hline & & $\boldsymbol{\beta}_{0}$ & $\beta_{1}$ & $\boldsymbol{\beta}_{2}$ & $\beta_{3}$ & & \\
\hline \multirow{7}{*}{$\begin{array}{l}\text { Parapiptadenia } \\
\text { rigida }\end{array}$} & Sch & 9.9513 & -925.4 & - & - & 37.75 & 1.56 \\
\hline & VB-R & 43.7913 & 0.000053 & 0.8691 & - & 34.42 & 1.43 \\
\hline & $C-J$ & 533 & -1.2948 & 0.0653 & 2.8678 & 35.12 & 1.46 \\
\hline & Pro & -14073.4 & 302.6 & 0.00657 & - & 33.38 & 1.38 \\
\hline & Mit & 97.2811 & 0.9925 & 0.000025 & - & 36.63 & 1.52 \\
\hline & Gom & 192.3 & 4.931 & 0.000185 & - & 32.56 & 1.35 \\
\hline & B4P & 16.988 & 0.0652 & 0.4175 & 4.4619 & 36.13 & 1.50 \\
\hline \multirow{7}{*}{$\begin{array}{l}\text { Mimosa } \\
\text { scabrella }\end{array}$} & Sch & 4.9364 & -201.5 & - & - & 24.67 & 0.72 \\
\hline & VB-R & 4.4936 & 0.00252 & 1.0117 & - & 24.3 & 0.71 \\
\hline & C-J & 5.3578 & -0.0708 & -0.6795 & 502.4 & 17.78 & 0.52 \\
\hline & Pro & 3044.3 & 58.5306 & 0.1833 & - & 24.27 & 0.71 \\
\hline & Mit & 4.4816 & 1.0129 & 0.00255 & - & 24.29 & 0.71 \\
\hline & Gom & 4.302 & 2.1256 & 0.00403 & - & 24.6 & 0.72 \\
\hline & B4P & 4.8284 & 0.1434 & 0.4536 & 4.3258 & 24.34 & 0.71 \\
\hline \multirow{7}{*}{$\begin{array}{l}\text { Peltophorum } \\
\text { dubium }\end{array}$} & Sch & 10.4082 & -1051.8 & - & - & 26.58 & 1.13 \\
\hline & VB-R & 42.0389 & 0.000055 & 0.8688 & - & 23.97 & 1.02 \\
\hline & C-J & 52.7337 & -3.858 & -0.3189 & 4.9368 & 26.79 & 1.14 \\
\hline & Pro & -10654.3 & 296.9 & 0.0164 & - & 23.63 & 1.00 \\
\hline & Mit & 121.5000 & 0.9967 & 0.000023 & - & 23.76 & 1.01 \\
\hline & Gom & 14.7824 & 2.701 & 0.000562 & - & 24.11 & 1.02 \\
\hline & B4P & 14.3982 & 0.0318 & 0.506 & 3.4676 & 24.94 & 1.06 \\
\hline \multirow{7}{*}{$\begin{array}{l}\text { Eucalyptus } \\
\text { urophylla } \\
\times \text { E. grandis }\end{array}$} & Sch & 28.35 & -700 & - & - & 17.4 & 1.99 \\
\hline & VB-R & 26.1731 & 0.00078 & 1.3692 & - & 16.23 & 1.85 \\
\hline & C-J & 69.1835 & -0.6129 & -0.2858 & 18.5375 & 25.04 & 2.86 \\
\hline & Pro & 13238.9 & 50.1822 & 0.0246 & - & 16.24 & 1.86 \\
\hline & Mit & 30.9423 & 1.0364 & 0.000489 & - & 16.23 & 1.85 \\
\hline & Gom & 22.2104 & 3.0673 & 0.0015 & - & 16.57 & 1.89 \\
\hline & B4P & 28.3361 & 0.00611 & 0.7443 & 2.1138 & 16.25 & 1.86 \\
\hline \multirow{7}{*}{$\begin{array}{l}\text { Schizolobium } \\
\text { parahybae }\end{array}$} & Sch & 9.5564 & -987 & - & - & 34.21 & 1.13 \\
\hline & VB-R & 30.5062 & 0.000016 & 0.5416 & - & 37.68 & 1.25 \\
\hline & C-J & 26.279 & -1.1519 & -0.0418 & 0.9824 & 45.93 & 1.52 \\
\hline & Pro & -13475 & 296.4 & 0.0244 & - & 30.08 & 1.00 \\
\hline & Mit & 166.1000 & 0.997 & 0.000017 & - & 29.9 & 0.99 \\
\hline & Gom & 10.1216 & 2.5814 & 0.000793 & - & 30.15 & 1.00 \\
\hline & B4P & 10.2222 & 0.0001 & 1.175 & 0.9438 & 31.61 & 1.05 \\
\hline
\end{tabular}

mation of nonlinear regression models, we used the nonlinear procedure "proc nlin" of the Statistical Analysis System $\left(\mathrm{SAS}^{\circledast}\right)$ software.

\section{Comparison between model coefficients}

When the same model has been selected for more than one species, the model coefficients were compared for their equality. To this purpose, we use the likelihood ratio test with accuracy given by chi-square $\left(\chi^{2}\right)$ statistic (Regazzi \& Silva 2010). The method involves the addition of two independent variables, $D 1$ and $D 2$, in order to calculate the maximum likelihood estimates of the parameters under no restrictions in the parametric space $(\Omega)$ representing the complete model, and under restriction represented by $\omega$ in the reduced model.

The maximum likelihood ratio test $(L)$ for large samples of size $\mathrm{N}$ was applied using the following formula (Rao 1973 - eqn. 1):

$$
-2 \ln L=-N \ln \left(\frac{\widehat{\sigma}_{\Omega}^{2}}{\widehat{\sigma}_{\omega}^{2}}\right)
$$

where $\hat{\sigma}_{\Omega}{ }^{2}$ is the estimate of the maximum likelihood of $\sigma^{2}$ with no restriction on the parametric space, $\hat{\sigma}_{\varpi}{ }^{2}$ is the estimate of the maximum likelihood of $\sigma^{2}$ with restrictions placed on $\mathrm{H}_{0}$, and $\mathrm{N}$ is the number of observations.

The complete model was adjusted under no restrictions in $\Omega$, and the reduced model was adjusted with respect to restrictions defined in $\mathrm{H}_{0}$. When $\chi_{\text {calc }}^{2} \geq \chi_{\alpha}^{2}$ at the significance level $\alpha, H_{0}$ was rejected.

\section{Inclusion of climatic factors}

After the selection of the models showing the best fitting for each species, we included climate factors as additional predictors into the model equations. Climatic data were obtained from the weather station of the Brazilian National Institute of Meteorology, located $1500 \mathrm{~m}$ away from the study site $\left(27^{\circ} 39^{\prime} \mathrm{S}, 53^{\circ} 43^{\prime} \mathrm{W}\right)$. The following parameters were considered: mean temperature (Tmean), maximum (Tmax), minimum (Tmin), absolute minimum (Tminabs), absolute maximum (Tmaxabs); accumulated rainfall along the seasons (Prec); accumulated solar radiation along the season (Asr). The above climatic parameters were averaged over each season in the period 2008-2014.

The first step was to determine which of the climatic variables were most correlated with the dependent variable, i.e., tree height. The selection was undertaken using stepwise multiple regression techniques in SAS ${ }^{\oplus}$

The models obtained using the stepwise method were evaluated for the presence and magnitude of multicollinearity through the matrix condition number (ratio between the largest and smallest eigenvalues) and the variance inflation factors (VIFs). VIFs above 10 indicate a high degree of multicollinearity (Mansfield \& Helms 
1982), due to the high correlation between independent variables in the model. This can result in an increased variance of the coefficients, thus compromising the final estimates. Therefore, variables showing high VIFs were excluded from the analysis. Multicollinearity was considered weak, moderate or severe, when the condition number was $<100$, between 100 and 1000, or $>1000$, respectively (Montgomery et al. 2012).

The meteorological variables selected by the stepwise method were considered as additional explanatory variables; nonlinear models selected for each species were refitted. New parameters $\left(\beta_{\mathrm{n}}\right)$ were added to the models and the coefficients were reestimated.

\section{Results}

\section{Best fitting models}

The fit statistics for each model tested for each tree species are shown in Tab. 1. The best-fitting models selected for each species were: von Bertalanffy-Richards for Eucalyptus urophylla $\times E$. grandis, Parapiptadenia rigida and Peltophorum dubium; ClutterJones for Mimosa scabrella; Gompertz for Schizolobium parahybae.

\section{Comparison between model coefficients}

Tab. 2 reports the results of the likelihood ratio test performed for the three species modeled using the same model (von Bertalanffy-Richards). Based on $\chi^{2}$ statistic, the $\mathrm{H}_{\mathrm{o}}$ was rejected for the following combinations: (i) Eucalyptus urophylla $\times$ E. grandis $\times$ Parapiptadenia rigida (EU $\times \mathrm{PR}$ ); (ii) Eucalyptus urophylla $\times \mathrm{E}$. grandis $\times$ Peltophorum dubium $(E U \times P D)$. This demonstrated that the equations differed for at least one parameter, and therefore that the common equation (whose estimates are listed in $\omega$ ) cannot be used. Contrastingly, for the combination PR $\times$ DP (Parapiptadenia rigida $\times$ Peltophorum dubium), the hypothesis of equality of model parameters in the two groups (complete model and reduced model) was not rejected, thus the coefficients chosen were those listed in $\omega$.

\section{Estimating tree species' height}

To assess the change in tree height with age for the species studied, we plotted the growth curves obtained by the use of the best fitting models described above (Fig. 2). The best relationship between the observed and predicted values was detected for Eucalyptus urophylla $\times$ E. grandis. For this species, the average observed height (black line in Fig. 2) significantly diverges from the height predicted by the model (red line), likely due to frost occurrence in several years that has lowered the growth of trees at the study site. Similar gaps between the observed and predicted height values could also be noticed for the other studied species (Fig. 2).
Tab. 2 - Parameter estimation of the complete model $(\Omega)$ and reduced model $(\omega)$ for the species combinations Eucalyptus urophylla $\times$ E. grandis $(E U)$, Parapiptadenia rigida (PR) and Peltophorum dubium (PD). (SQRR): sum of squares residual of the regression; (DFRR) number of degrees of freedom of the regression residuals; $(N)$ : sample size; $\left(X_{\text {calc. }}^{2}\right)$ : calculated chi-square values; $(D F)$ : degrees of freedom $(P)$ : critical probability level.

\begin{tabular}{|c|c|c|c|c|c|c|}
\hline \multirow{3}{*}{ Parameters } & \multicolumn{6}{|c|}{ Species combination } \\
\hline & \multicolumn{2}{|c|}{$E U \times P R$} & \multicolumn{2}{|c|}{$E U \times P D$} & \multicolumn{2}{|c|}{$P R \times P D$} \\
\hline & $\Omega$ & $\omega$ & $\Omega$ & $\omega$ & $\Omega$ & $\omega$ \\
\hline$\beta_{0 \mathrm{a}}$ & 26.1731 & - & 26.1731 & - & 43.7913 & - \\
\hline$\beta_{1 \mathrm{a}}$ & 0.00078 & - & 0.00078 & - & 0.000053 & - \\
\hline$\beta_{2 a}$ & 1.3692 & - & 1.3692 & - & 0.8691 & - \\
\hline$\beta_{0 \mathrm{~b}}$ & 43.7913 & - & 42.0389 & - & 42.0389 & - \\
\hline$\beta_{1 \mathrm{~b}}$ & 0.000053 & - & 0.000055 & - & 0.000055 & - \\
\hline$\beta_{2 \mathrm{~b}}$ & 0.8691 & - & 0.8688 & - & 0.8688 & - \\
\hline$\beta_{0}$ & - & 35.6397 & - & 16.2705 & - & 42.9151 \\
\hline$\beta_{1}$ & - & 0.000176 & - & 0.000624 & - & 0.000054 \\
\hline$\beta_{2}$ & - & 0.847 & - & 1.06 & - & 0.869 \\
\hline $\begin{array}{l}\text { SQRR } \\
\text { DFRR }\end{array}$ & 1814.9 & $\begin{array}{c}14865.4 \\
653\end{array}$ & $\begin{array}{c}1608.4 \\
738\end{array}$ & $\begin{array}{c}17700.1 \\
741\end{array}$ & $\begin{array}{c}1003.107 \\
684\end{array}$ & $\begin{array}{c}1003.9 \\
687\end{array}$ \\
\hline $\begin{array}{l}\text { DFRR } \\
\text { N }\end{array}$ & \multirow{2}{*}{\multicolumn{2}{|c|}{656}} & \multirow{2}{*}{\multicolumn{2}{|c|}{744}} & \multirow{2}{*}{\multicolumn{2}{|c|}{690}} \\
\hline$\chi_{\text {calc. }}^{2}$ & & & & & & \\
\hline $\mathrm{DF}\left(\chi^{2}\right)$ & \multicolumn{2}{|c|}{$\begin{array}{c}1379.57 \\
3\end{array}$} & \multicolumn{2}{|c|}{$\begin{array}{c}1 / 84.35 \\
3\end{array}$} & \multicolumn{2}{|c|}{$\begin{array}{c}0.55 \\
3\end{array}$} \\
\hline$P\left(\chi_{v}^{2}>\chi_{\text {calc. }}^{2}\right)$ & \multicolumn{2}{|c|}{$1.46 \times 10^{-12}$} & \multicolumn{2}{|c|}{$1.88 \times 10^{-12}$} & \multicolumn{2}{|c|}{0.91} \\
\hline
\end{tabular}

\section{Selection of climatic factors}

tree height growth, as tree growth does The inclusion of climatic factors in the not only depend on age. The climate varimodels described above aimed at bridging ables tested at the study site are shown in the gap between observed and predicted Tab. 3. A wide variation in several climatic

Tab. 3 - Mean temperature (Tmean), maximum (Tmax), minimum (Tmin), absolute minimum (Tminabs), absolute maximum (Tmaxabs); accumulated rainfall (Prec) along the seasons; accumulated solar radiation (Asr) along the season. Data are means over each season for the period 2008-2014 (source: Brazilian National Institute of Meteorology).

\begin{tabular}{|c|c|c|c|c|c|c|c|c|}
\hline \multirow[b]{2}{*}{ Years } & \multirow[b]{2}{*}{ Seasons } & \multicolumn{7}{|c|}{ Climatic factors } \\
\hline & & $\begin{array}{c}\text { Tmean } \\
\left({ }^{\circ} \mathrm{C}\right)\end{array}$ & $\begin{array}{c}\operatorname{Tmax} \\
\left({ }^{\circ} \mathrm{C}\right)\end{array}$ & $\begin{array}{c}T \operatorname{Tmin} \\
\left({ }^{\circ} \mathrm{C}\right)\end{array}$ & $\begin{array}{c}\text { Tmaxabs } \\
\left({ }^{\circ} \mathrm{C}\right)\end{array}$ & $\begin{array}{c}\text { Tminabs } \\
\left({ }^{\circ} \mathrm{C}\right)\end{array}$ & $\begin{array}{l}\text { Prec } \\
(\mathrm{mm})\end{array}$ & $\begin{array}{c}\text { Asr } \\
\left(M^{-2} \mathrm{~m}^{-2}\right)\end{array}$ \\
\hline \multirow[t]{4}{*}{2008} & Summer & 23.24 & 24.04 & 22.48 & 34.00 & 13.40 & 333.20 & 2034.08 \\
\hline & Autumn & 16.73 & 17.47 & 16.00 & 31.80 & -2.10 & 526.60 & 3245.71 \\
\hline & Winter & 16.15 & 16.80 & 15.52 & 32.70 & 0.40 & 316.40 & 4396.92 \\
\hline & Spring & 20.43 & 21.15 & 19.76 & 36.70 & 4.70 & 587.00 & 6309.70 \\
\hline \multirow[t]{4}{*}{2009} & Summer & 23.32 & 24.10 & 22.57 & 35.10 & 12.50 & 293.20 & 8311.97 \\
\hline & Autumn & 18.12 & 18.92 & 17.34 & 33.80 & -0.60 & 359.00 & 9620.18 \\
\hline & Winter & 15.03 & 15.65 & 14.44 & 31.30 & -2.70 & 671.60 & 10664.73 \\
\hline & Spring & 21.19 & 21.86 & 20.56 & 35.90 & 5.60 & 730.00 & 12389.98 \\
\hline \multirow[t]{4}{*}{2010} & Summer & 24.07 & 24.80 & 23.39 & 35.70 & 13.60 & 478.80 & 14306.95 \\
\hline & Autumn & 17.10 & 17.69 & 16.54 & 31.50 & 3.00 & 706.80 & 15377.76 \\
\hline & Winter & 15.56 & 16.17 & 14.95 & 31.30 & -1.80 & 312.60 & 16509.36 \\
\hline & Spring & 19.68 & 20.44 & 18.96 & 33.10 & 6.70 & 589.80 & 18393.55 \\
\hline \multirow[t]{4}{*}{2011} & Summer & 23.39 & 24.11 & 22.73 & 33.36 & 13.10 & 464.20 & 20293.52 \\
\hline & Autumn & 17.32 & 17.99 & 16.68 & 31.10 & 2.40 & 425.80 & 21481.79 \\
\hline & Winter & 14.97 & 15.56 & 14.41 & 31.70 & -2.60 & 892.80 & 22505.30 \\
\hline & Spring & 20.67 & 21.47 & 19.89 & 34.70 & 8.50 & 436.80 & 24599.31 \\
\hline \multirow[t]{4}{*}{2012} & Summer & 24.57 & 25.47 & 23.71 & 37.00 & 13.30 & 252.40 & 26781.67 \\
\hline & Autumn & 17.17 & 17.91 & 16.46 & 32.00 & -2.20 & 295.80 & 28021.24 \\
\hline & Winter & 17.16 & 17.82 & 16.51 & 35.70 & 0.90 & 328.40 & 29391.31 \\
\hline & Spring & 21.57 & 22.31 & 20.85 & 34.80 & 2.30 & 598.00 & 31482.57 \\
\hline \multirow[t]{4}{*}{2013} & Summer & 22.39 & 23.10 & 21.71 & 35.90 & 11.50 & 573.60 & 33479.46 \\
\hline & Autumn & 17.12 & 17.81 & 16.46 & 29.90 & 3.00 & 435.60 & 34911.44 \\
\hline & Winter & 14.72 & 15.38 & 14.08 & 32.90 & -1.80 & 520.60 & 36222.07 \\
\hline & Spring & 20.78 & 21.50 & 20.10 & 34.10 & 5.60 & 510.80 & 38423.17 \\
\hline \multirow[t]{4}{*}{2014} & Summer & 23.89 & 24.66 & 23.14 & 36.70 & 12.30 & 556.80 & 40636.56 \\
\hline & Autumn & 17.42 & 18.03 & 16.85 & 32.00 & 3.00 & 710.40 & 41978.62 \\
\hline & Winter & 16.46 & 17.07 & 15.87 & 32.60 & 1.10 & 707.60 & 43298.17 \\
\hline & Spring & 22.05 & 22.75 & 21.39 & 35.80 & 9.30 & 659.80 & 45403.82 \\
\hline
\end{tabular}



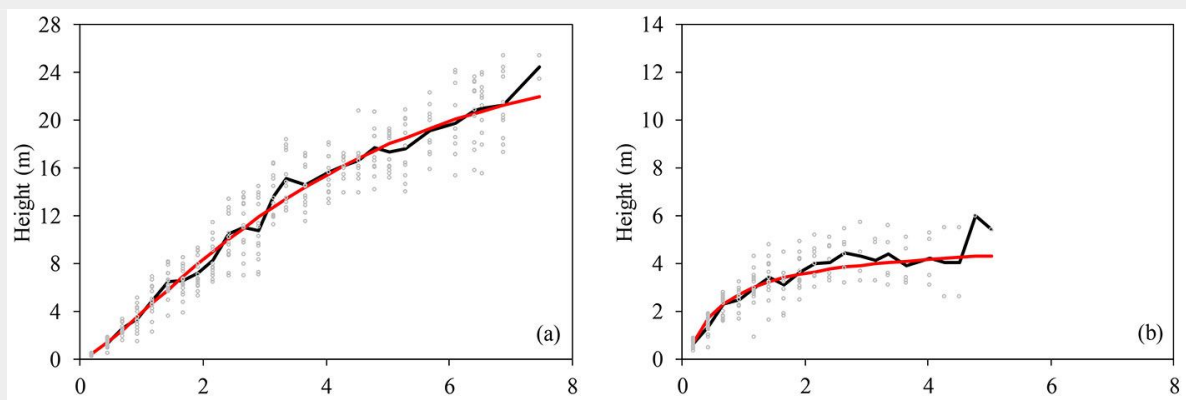

Fig. 2 - Height growth curve according to age for different forest tree species. Grey dots represents the observed tree height values, the black line is the average of the observed heights in each year of observation, while the red line represents the predicted tree height at different ages obtained by the best-fitting model for each tree species. (a) Eucalyptus urophylla $\times$ E. grandis; (b)
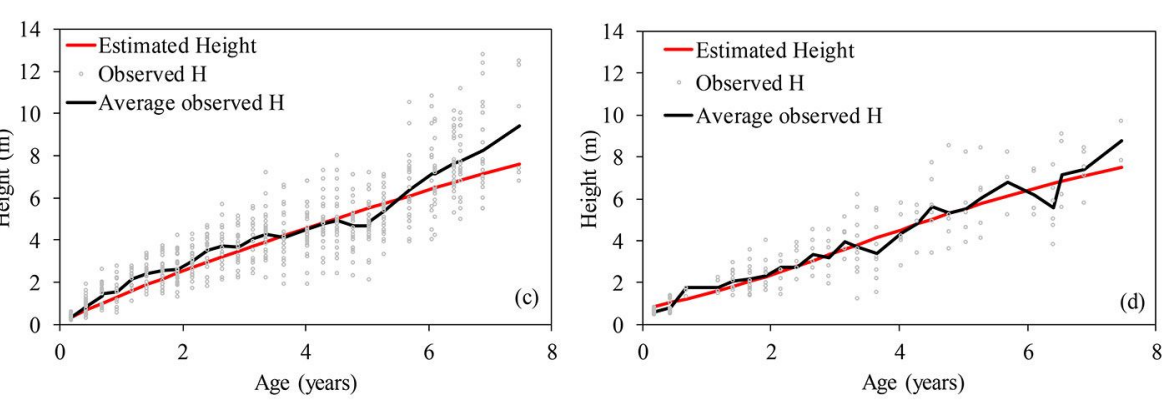

Mimosa scabrella; (c) Parapiptadenia rigida and Peltophorum dubium; (d) Schizolobium parahybae.
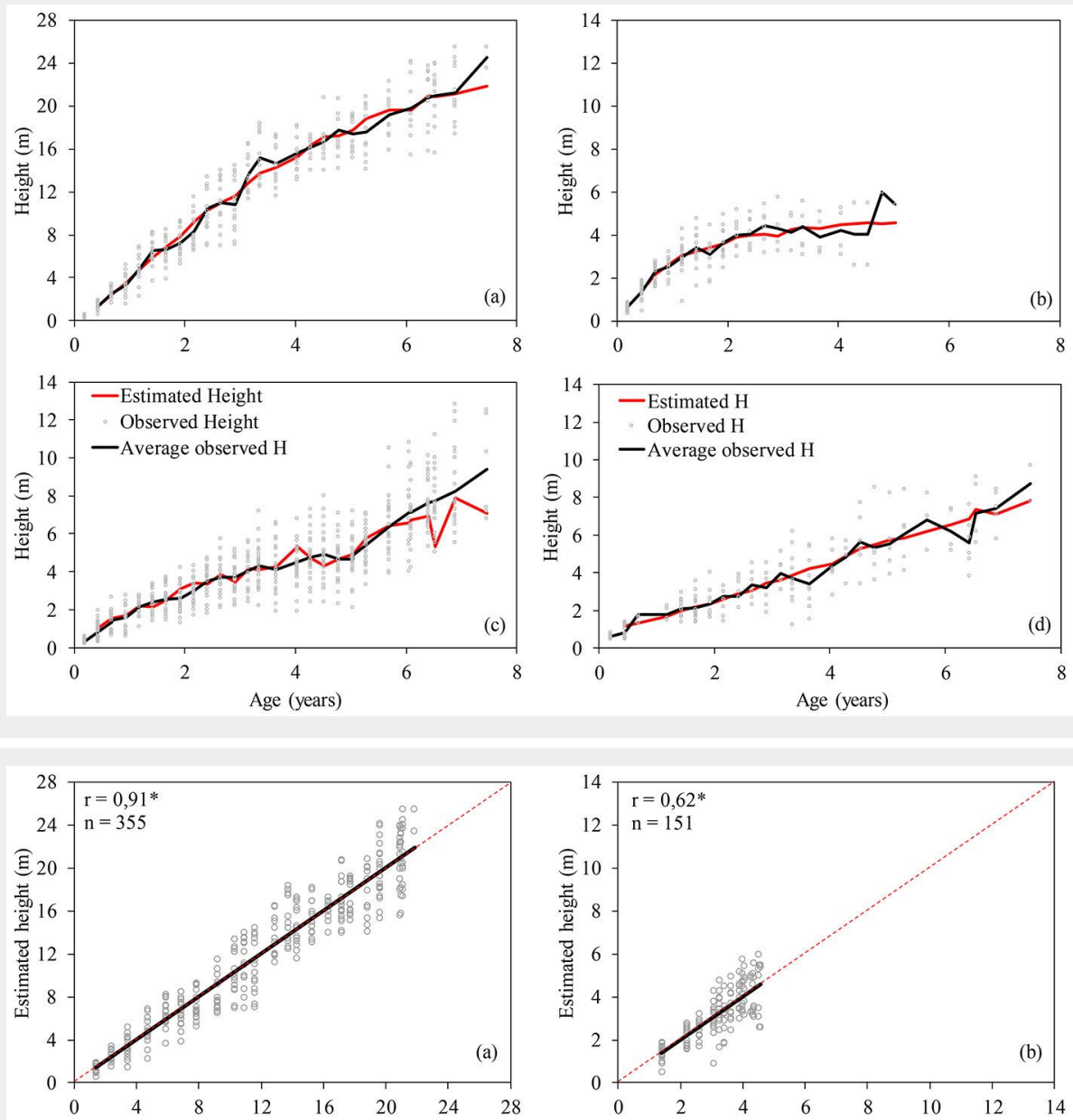

Fig. 3 - Height growth curve according to age and climatic factors of different forest tree species. Grey dots represents the observed tree height values, the black line is the average of the observed heights in each year of observation, while the red line represents the predicted tree height at different ages obtained after the inclusion of climatic parameters in the models for each tree species. (a) Eucalyptus urophylla $\times E$. grandis; (b) Mimosa scabrella; (c) Parapiptadenia rigida and Peltophorum dubium; (d) Schizolobium parahybae.
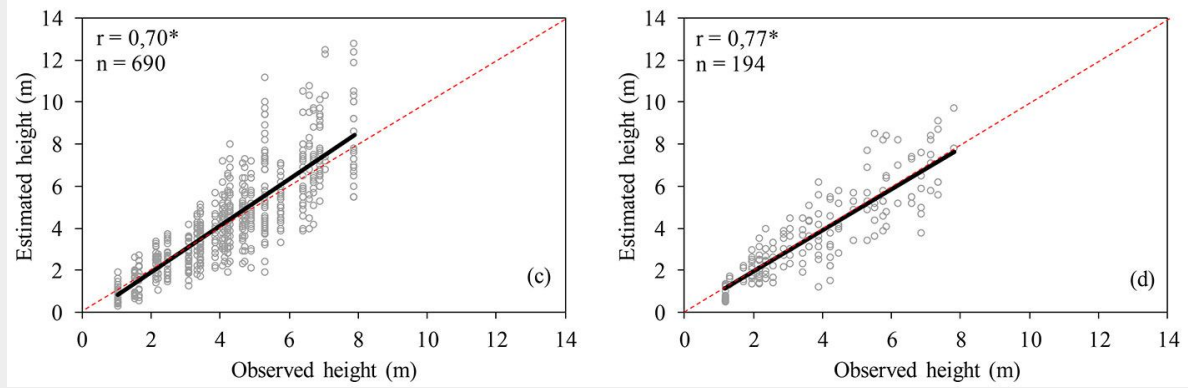

Fig. 4 - Relationship between estimated and observed height after the inclusion of climatic variables into tree height models: (a) Eucalyptus urophylla $\times E$. grandis; (b) Mimosa scabrella; (c) Parapiptadenia rigida and Peltophorum dubium; (d) Schizolobium parahybae. 
Tab. 4 - Fit statistics and coefficients obtained by adjusting four nonlinear models based on climatic factors and tree age, to describe the height growth of different tree species. (CV): coefficient of variation; (SE): standard error.

\begin{tabular}{lcccccccc}
\hline \multirow{2}{*}{ Species } & \multicolumn{3}{c}{ Coefficients } & \multicolumn{3}{c}{} & & \multicolumn{2}{c}{ CV (\%) } & \multirow{2}{*}{ SE (m) } \\
\cline { 2 - 7 } & $\boldsymbol{\beta}_{0}$ & $\boldsymbol{\beta}_{1}$ & $\boldsymbol{\beta}_{2}$ & $\boldsymbol{\beta}_{3}$ & $\boldsymbol{\beta}_{4}$ & $\boldsymbol{\beta}_{5}$ & & \\
\hline Eucalyptus urophylla $\times$ E. grandis & 0.0109 & 0.1028 & 17.8813 & 0.0008 & 1.3824 & - & 16.61 & 0.58 \\
Mimosa scabrella & 0.0431 & 0.0871 & 7.1046 & -1.663 & -0.1112 & 0.7324 & 25.74 & 0.75 \\
Parapiptadenia rigida, Peltophorum dubium & 0.2192 & 10.5684 & 0.000023 & 0.6399 & - & - & 31.17 & 1.31 \\
Schizolobium parahybae & -0.0424 & 1.0002 & 15.0384 & 2.579 & -0.0007 & - & 31.60 & 1.05 \\
\hline
\end{tabular}

parameters was observed over the years, as well as the irregularity of rainfall across years and the occurrence of absolute minimum temperature lower than zero.

The climatic variables selected by the stepwise regression analysis were: Asr, Tmin and Prec for the Eucalyptus urophylla $\times$ E. grandis, Parapiptadenia rigida e Peltophorum dubium; Asr, Tmin, Prec and Tmean for Mimosa scabrella; Asr, Tminabs and Prec for Schizolobium parahybae. The very high correlation observed between independent variables indicates the presence of multicollinearity, as reported by Neter \& Wasserman (1974) and Sanquetta et al. (2014). In this study, we used VIF $=10$ as threshold for multicollinearity detection (Mansfield \& Helms 1982). The variables with high VIFs were age $(A)$ and Asr; therefore Asr was excluded from the model. Its exclusion led to VIFs $<10$, thus multicollinearity was considered weak by the selection methods.

\section{Final models}

After the inclusion of climate variables, the best nonlinear models formerly selected were re-fitted and the parameters were tested for their significance by $t$ tests. Tab. S2 in Supplementary material reports the final models after the inclusion of the climatic parameters and the species used in each model.

The adjusted coefficients for each final model are reported in Tab. 4 . It is worth to notice that the inclusion of climatic parameters into the final models fairly reduced the gaps between the observed and predicted values of tree height growth (Fig. 3, Fig. 4). The residual analyses of these relationships are presented in Fig. S1 (Supplementary material) for each species.

A comparison between by the traditional biological models and the final models including tree age and climatic factors as predictors is displayed in Fig. 5.

\section{Discussion}

In this study, the non-linear regression models selected for estimating the height growth of each tree species considered seem biologically meaningful, and their fit statistics were satisfactory. In general, the von Bertalanffy-Richards model showed the best fit in most cases. Several authors have attributed the good performances of this model to its capacity to adequately describe the ecological/biological processes underlying tree growth (Zeide 1993, Ro- hner et al. 2013, David et al. 2015).

The inclusion of climatic variables into the height growth models (Fig. 3) allowed to obtain more accurate estimates of tree height growth with age, as compared with those obtained using curves based on traditional nonlinear models. The standard error of the models was satisfactory and the coefficient of variation was acceptable
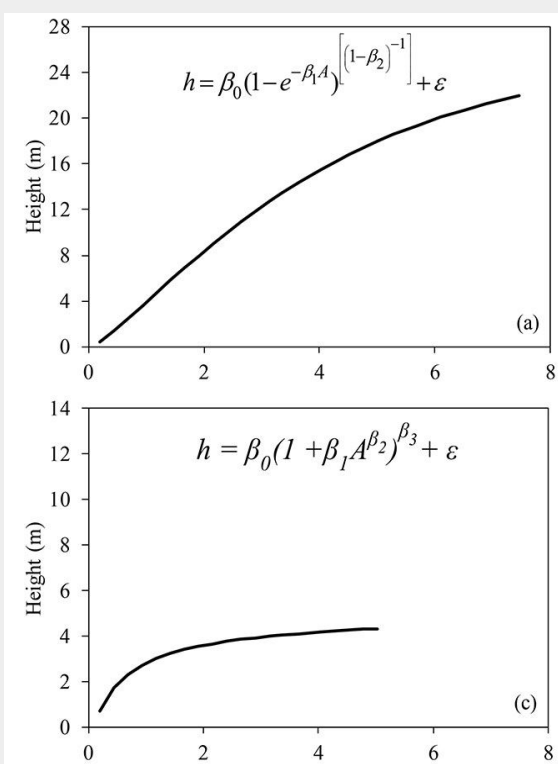

(Tab. 4). In addition, the good consistency between observed and estimated values for all species in the models was detected by correlation analysis (Fig. 4).

It can be noticed that the minimum temperature and the accumulated rainfall over the seasons were the climatic parameters included in almost all the final models, and were therefore considered as the factors
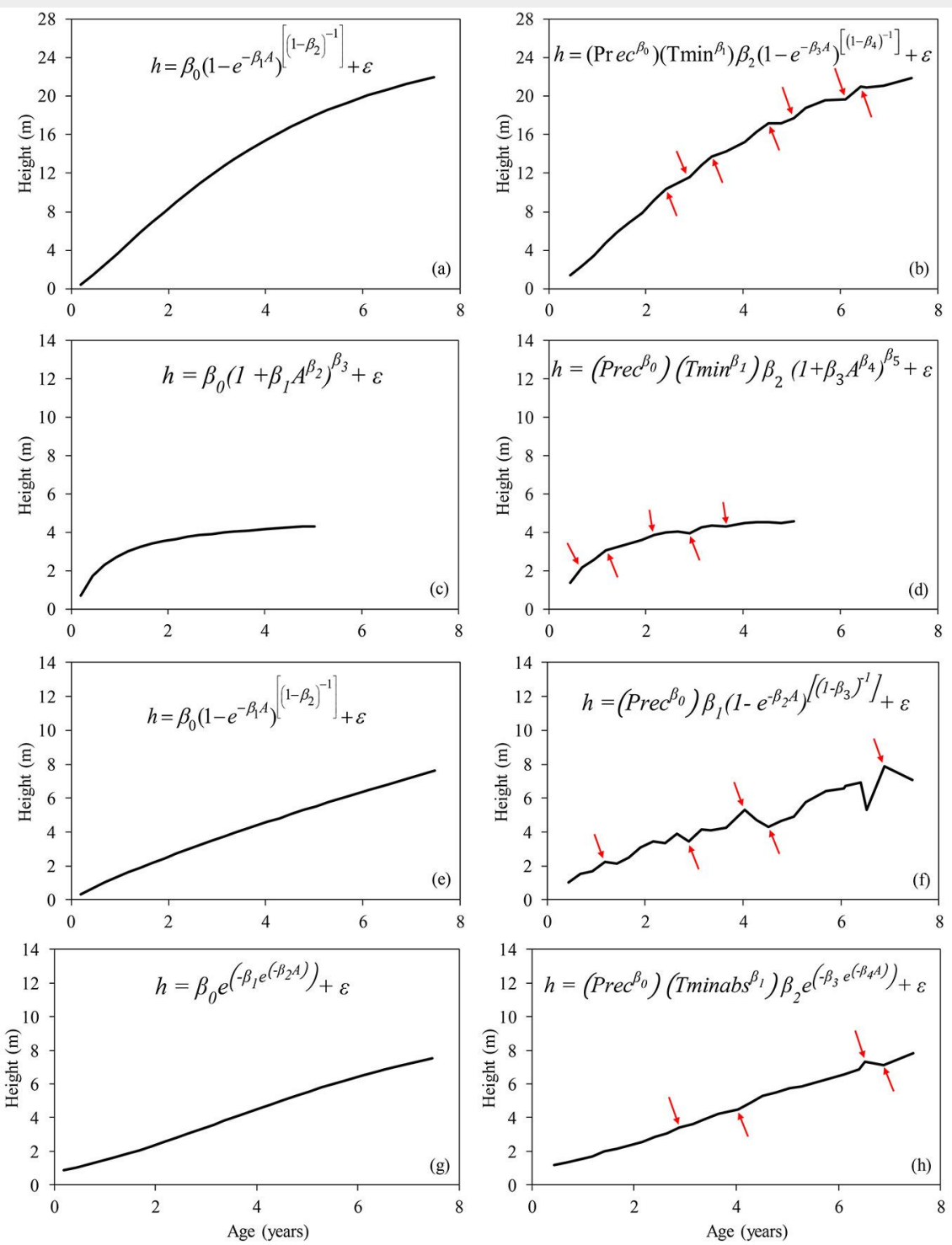

Fig. 5 - Variation in height growth curves before (left column: a, c, e, g) and after (right column: b, $d, f, h$ ) the inclusion of climatic factors in the traditional best-fitting models. The main differences between growth curves are indicated by red arrows. (a, b): Eucalyptus urophylla $\times$ Eucalyptus grandis; (c, d): Mimosa scabrella; (e, f): Parapiptadenia rigida and Peltophorum dubium; (g, h): Schizolobium parahybae. 

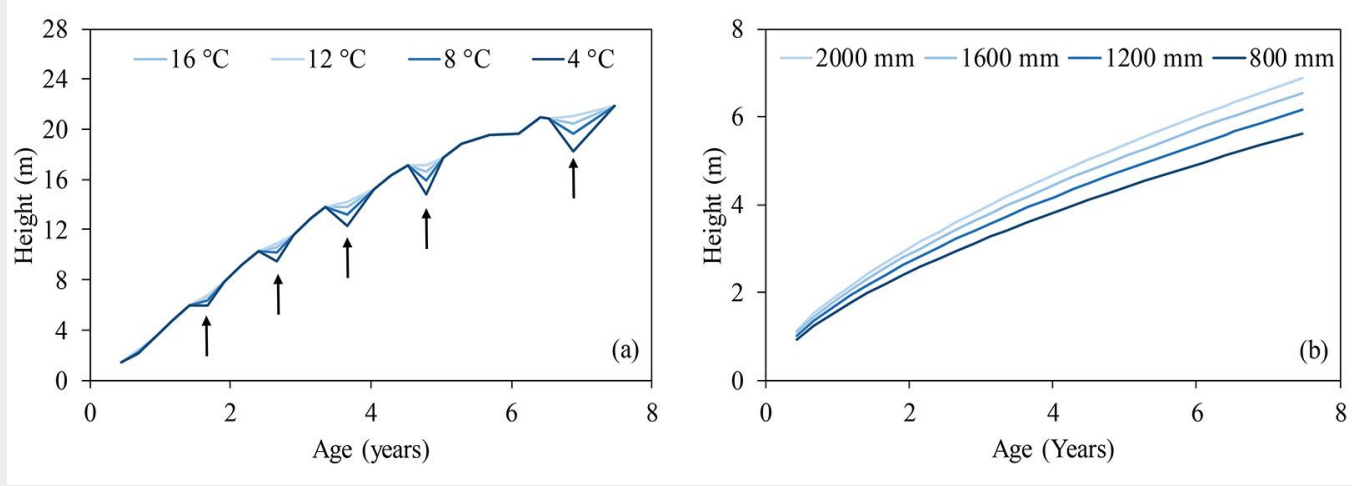

Fig. 6 - Simulating height growth with age in Eucalyptus urophylla $\times E$. grandis at different minimum temperatures (a), using the model $h=\left(\operatorname{Prec}^{\beta 0}\right)\left(\operatorname{Tmin}^{\beta 1}\right) \beta_{2}(1-$ $\left.\mathrm{e}^{-\beta 3 A}\right)^{1 /(-\beta 4)}+\varepsilon$; Parapiptadenia rigida and Peltophorum dubium at different annual rainfall (b), using the model $h=\left(\operatorname{Prec}^{\beta 0}\right) \beta_{1}\left(1-\mathrm{e}^{-\beta 2 A}\right)^{1 /\left(1-\beta_{3}\right)}+$ $\varepsilon$. Black arrows represent the damage due to frosts in winter.

most affecting tree growth. The modifications of the growth curves after the inclusion of climatic parameters in the best fitting models are shown in Fig. 5. At many points along the curve, variations were observed in tree height (Fig. 5b, Fig. 5d, Fig. $5 f$ and Fig. 5h) that were not identified using the traditional nonlinear models (Fig. 5a, Fig. 5c, Fig. 5e and Fig. 5g).

The impact of low temperatures on tree growth may vary depending on the species sensitivity, tree age, type of plant structure or organ, intensity of the minimum temperature and the occurrence and frequency of frost. This may result in the reduction of tree growth rate or biomass loss of the stem apex and leaves. Hendrickson et al. (2004) found that minimum temperatures from 1 to $3{ }^{\circ} \mathrm{C}$ reduce the growth rate of Vitis vinifera by $34-63 \%$. Gatti et al. (2008) showed that low temperatures affect the photosynthetic rate of Euterpe edulis. Wang et al. (2011) found that the occurrence of frost caused $31.3 \%$ defoliation of exposed shoots of Kandelia ovata. Augspurger (2011) found that the death of branches reduced the canopy percentage, contributed to early senescence and reduced growth, and led to the death of Aesculus glabra yolks. Other studies showed that the occurrence of frost affects plant organs and their growth (Strain 1966, Luken 1990), survival (Mooney 1977), reproduction (Inouye 2008) and demographic distribution (Inouye 2000). Freezing of extracellular solutions determines the senescence of leaves and stems, resulting in an imbalance between the chemical potential of intra and extra-cellular water. This leads to the water transfer outwards that causes cellular dehydration, decreased cell turgor, solute accumulation and rupture of the plasma membrane (Heber \& Santarius 1973).

In this study we performed a simulation to explore the influence of different levels of minimum temperature occurring in winter and different annual rainfall regimes, on the height growth of the tree species studied, based on the model obtained (Fig. 6 ). The results confirmed that higher rainfall regimes have a positive impact on tree growth. This is consistent with the findings of Sanquetta et al. (2014), who observed that the growth of Acacia mearnsii depends of available water content in the soil. Morales et al. (2004) found high correlations between precipitation and the growth of Juglans australis, Alnus acuminata, Prosopis ferox and Polylepis tarapacana. Dünisch et al. (2003) and Grogan \& Schulze (2012) obtained similar results with Swietenia macrophylla. Allen \& Albaugh (1999) reported that low water availability and extreme temperatures negatively affect the leaf area and the interception and use of solar radiation in Pinus taeda, influencing their overall growth.

The water availability in the soil directly affects the transpiration rate, stomatal conductance, and photosynthesis (Schippers et al. 2015), because the opening and closing of stomata are controlled by soil water potential. The absence of water stress allows increased internal $\mathrm{CO}_{2}$ concentration in the leaves due to greater stomatal conductance, increasing the photosynthetic rate (Lloyd \& Farquhar 2008, Van Der Sleen et al. 2014). These studies are in agreement with the results obtained in this study and with the climatic variables selected in the proposed models. The fact that the traditional nonlinear regression approach lead to a loss of path invariance can be considered, but the proposed models provide satisfactory estimates of the height of tree species, use easily obtainable input variables and are easily applicable in several forestry studies and practical situations.

\section{Conclusions}

Our results showed that the von Bertalanffy-Richards, Clutter-Jones and Gompertz models are more flexible in representing the growth of Eucalyptus urophylla $x$ Eucalyptus grandis, Parapiptadenia rigida, Peltophorum dubium, Mimosa scabrella and Schizolobium parahybae.

The inclusion of climatic factors into such models improved their prediction of tree height growth with age. More accurate estimates were especially obtained by including minimum temperature and rainfall. Using the developed models, tree species growth can be simulated by changing weather conditions, thus providing useful information for the achievement of adequate forest management.

\section{Acknowledgements}

The authors acknowledge the National Council for Scientific and Technological Development (CNPq - Brazil) and the Coordination for the Improvement of Higher Education Personnel (CAPES - Brazil) for their financial support.

\section{References}

Allen H, Albaugh TJ (1999). Ecophysiological basis for plantation production: a loblolly pine case study. Bosque 20: 3-8. - doi: 10.4206/bos que.1999.v20n1-01

Armstrong RA, McGhee R (1980). Competitive exclusion. American Naturalist 115: 151-170. - doi: 10.1086/283553

Augspurger CK (2011). Frost damage and its cascading negative effects on Aesculus glabra. Plant Ecology 212: 1193-1203. - doi: 10.1007/s1125 8-011-9897-z

David HC, Péllico Netto S, Arce JE, Corte A, Marinheski Filho A, Behling A (2015). Updating of dominant height growth modeling and site index of Pinus taeda L. in southern Brazil. Australian Journal of Basic and Applied Sciences 9: 115-125. [online] URL: http://oaji.net/articles/20 15/464-1444671189.pdf

Diamantopoulou MJ, Ozçelik R (2012). Evaluation of different modeling approaches for total tree-height estimation in Mediterranean region of Turkey. Forest Systems 21: 383-397. - doi: 10.5424/fs/2012213-02338

Dünisch O, Montóia VR, Bauch J (2003). Dendroecological investigations on Swietenia macrophylla King and Cedrela odorata L. (Meliaceae) in the central Amazon. Trees 17: 244250. - doi: 10.1007/s00468-002-0230-2

Fitter AH (1987). An architectural approach to the comparative ecology of plant root systems. New Phytologist 106: 61-77. - doi: 10.1111/j.14698137.1987.tbo4683.x

Gatti MG, Campanello PI, Montti LF, Goldstein G (2008). Frost resistance in the tropical palm Euterpe edulis and its pattern of distribution in the Atlantic Forest of Argentina. Forest Ecology and Management 256: 633-640. - doi: 10.1016/ j.foreco.2008.05.012

Grogan J, Schulze M (2012). The impact of annual and seasonal rainfall patterns on growth and phenology of emergent tree species in southeastern Amazonia, Brazil. Biotropica 44: 331340. - doi: 10.1111/j.1744-7429.2011.00825.x Heber U, Santarius KA (1973). Cell death by cold and heat and resistance to extreme temperatures: mechanisms of hardening and deharden- 
ing. In: "Temperature and life" (Precht H, Christophersen J, Hensel H, Larcher W eds). Springer-Verlag, Berlin, Germany, pp. 232-292.

Hendrickson L, Ball MC, Wood JT, Chow WS, Furbank RT (2004). Low temperature effects on photosynthesis and growth of grapevine. Plant, Cell and Environment 27: 795-809. - doi: 10.1111/j.1365-3040.2004.01184.x

Hunter IR, Gibson AR (1984). Predicting Pinus radiata site index from environmental variables. New Zealand Journal of Forestry Science 14: 53-64. [online] URL: http://www.scionre search.com/_data/assets/pdf_file/0014/30920/ NZJFS1411984HUNTER53_64.pdf

Inouye DW (2000). The ecological and evolutionary significance of frost in the context of climate change. Ecology Letters 3: 457-463. - doi: 10.1046/j.1461-0248.2000.00165.x

Inouye DW (2008). Effects of climate change on phenology, frost damage, and floral abundance of montane wildflowers. Ecology 89: 353-362. doi: 10.1890/06-2128.1

Jiang L, Li Y (2010). Application of nonlinear mixed-effects modeling approach in tree height prediction. Journal of Computers 5: 1575-1581. doi: $10.4304 /$ jcp.5.10.1575-1581

Jose S, Gillespie AR, Pallardy SG (2004). Interespecific interactions in temperate agroforestry. Agroforestry Systems 61: 237-255. - doi: 10.1023/ B:AGFO.0000029002.85273.9b

Lloyd J, Farquhar GD (2008). Effects of rising temperatures and $\mathrm{CO}_{2}$ on the physiology of tropical forest trees. Philosophical Transactions of the Royal Society B: Biological Sciences 363 : 1811-1817. - doi: 10.1098/rstb.2007.0032

Lohmus K, Oja T, Lasn R (1989). Specific root area: soil characteristic. Plant and Soil 119: 245249. - doi: 10.1007/BF02370415

Luken JO (1990). Gradual and episodic changes in the structure of Rhus typhina clones. Bulletin of the Torrey Botanical Club 117: 221-225. - doi: $10.2307 / 2996690$

Mansfield ER, Helms BP (1982). Detecting multicollinearity. The American Statistician 36: 158160. - doi: 10.1080/00031305.1982.10482818

Montgomery DC, Peck EA, Vining GG (2012). Introduction to linear regression analysis $\left(5^{\text {th }}\right.$ edn). John Wiley and Sons, New Jersey, USA, pp. 507. [online] URL: http://books.google. com/books?id=27kOCgAAQBAJ

Mooney HA (1977). Frost sensitivity and resprouting behavior of analogous shrubs of California and Chile. Madroño 24: 74-78. [online] URL: http://www.jstor.org/stable/41424091

Morales MS, Villalba R, Grau HR, Paolini L (2004). Rainfall-controlled tree growth in high-elevation subtropical treelines. Ecology 85: 30803089. - doi: 10.1890/04-0139

Neter J, Wasserman W (1974). Applied linear statistical models: regression, analysis of variance, and experimental designs. Richard D. Irwin, Homewood, IL, USA, pp. 842.

Newman El (1973). Competition and diversity in herbaceous vegetation. Nature 244: 310-1310. doi: $10.1038 / 244310 a 0$

Perin J, Hébert J, Brostaux Y, Lejeune P, Claessens $H$ (2013). Modelling the top-height growth and site index of Norway spruce in Southern
Belgium. Forest ecology and management 298: 62-70. - doi: 10.1016/j.foreco.2013.03.009

Prior LD, Bowman DMJS (2014). Big eucalypts grow more slowly in a warm climate: evidence of an interaction between tree size and temperature. Global change biology 20: 2793-2799. - doi: 10.1111/gcb.12540

Rais A, Van De Kuilen JWG, Pretzsch H (2014). Growth reaction patterns of tree height, diameter, and volume of Douglas-fir (Pseudotsuga menziesii [Mirb.] Franco) under acute drought stress in Southern Germany. European Journal of Forest Research 133: 1043-1056. - doi: 10.1007 /s10342-014-0821-7

Rao CR (1973). Linear statistical inference and its applications. Wiley Series in Probability and Statistics, John Wiley \& Sons, New York, USA, pp. 560. - doi: 10.1002/9780470316436

Rasche L, Fahse L, Zingg A, Bugmann H (2012). Enhancing gap model accuracy by modeling dynamic height growth and dynamic maximum tree height. Ecological Modelling 232: 133-143. doi: 10.1016/j.ecolmodel.2012.03.004

Regazzi AJ, Silva CHO (2010). Testes para verificar a igualdade de parametros e a identidade de modelos de regressão não-linear em dados de experimento com delineamento em blocos casualizados [Tests for model identity and parameter equality with nonlinear regression models in data from randomized complete block design]. Ceres 57: 315-320. [in Portuguese] - doi: 10.1590/S0034-737X2010000300005

Rohner B, Bugmann H, Bigler C (2013). Estimating the age-diameter relationship of oak species in Switzerland using nonlinear mixed-effects models. European Journal of Forest Research 132 (5-6): 751-764. - doi: 10.1007/s10342013-0710-5

Sanquetta CR, Behling A, Dalla Corte AP, Netto SP, Rodrigues AL, Simon AA (2014). A model based on environmental factors for diameter distribution in black wattle in Brazil. Plos ONE 9: e100093. - doi: 10.1371/journal.pone.0100093 Schippers P, Sterck F, Vlam M, Zuidema PA (2015). Tree growth variation in the tropical forest: understanding effects of temperature, rainfall and $\mathrm{CO}_{2}$. Global Change Biology 21: 2749-2761. - doi: 10.1111/gcb.12877

Snowdon P, Benson ML, Woollons RC (1998). Incorporation of climatic indices into models of growth of Pinus radiata in a spacing experiment. New Forests 16: 101-123. - doi: 10.1023/A: 1006524609459

Snowdon P, Jovanovic T, Booth TH (1999). Incorporation of indices of annual climatic variation into growth models for Pinus radiata. Forest Ecology and Management 117: 187-197. - doi: 10.1016/S0378-1127(98)00463-0

Strain BR (1966). The effect of a late spring frost on the radial growth of variant quaking aspen biotypes. Forest Science 12: 334-337. [online] URL: http://www.ingentaconnect.com/content/ saf/fs/1966/00000012/00000003/art00017

Subedi N, Sharma M (2013). Climate-diameter growth relationships of black spruce and jack pine trees in boreal Ontario, Canada. Global Change Biology 9: 505-516. - doi: 10.1111/gcb.12 033
Trouvé R, Bontemps JD, Seynave I, Collet C, Lebourgeois F (2015). Stand density, tree social status and water stress influence allocation in height and diameter growth of Quercus petraea (Liebl.). Tree physiology 35: 1035-1046. doi: 10.1093/treephys/tpv067

Uzoh FC, Oliver WW (2006). Individual tree height increment model for managed evenaged stands of ponderosa pine throughout the western United States using linear mixed effects models. Forest Ecology and Management 221: 147-154. - doi: 10.1016/j.foreco.2005.09.012 Van Der Sleen P, Groenendijk P, Vlam M, Anten NP, Boom A, Bongers F, Pons TL, Teburg G, Zuidema PA (2014). No growth stimulation of tropical trees by 150 years of $\mathrm{CO}_{2}$ fertilization but water-use efficiency increased. Nature Geoscience 8: 24-28. - doi: 10.1038/ngeo2313

Wang W, You S, Wang Y, Huang L, Wang M (2011). Influence of frost on nutrient resorption during leaf senescence in a mangrove at its latitudinal limit of distribution. Plant and Soil 342: 105-115. - doi: 10.1007/s11104-010-0672-z

Woollons RC, Snowdon P, Mitchell ND (1997). Augmenting empirical stand projection equations with edaphic and climatic variables. Forest Ecology and Management 98: 267-275. - doi: 10.1016/S0378-1127(97)0oo9o-X

Zeide B (1993). Analysis of growth equations. Forest Science 39: 594-616. [online] URL: http:// www.ingentaconnect.com/content/saf/fs/1993/ 00000039/00000003/artoo014

Zhang PC, Liu J (2001). Developing and validating nonlinear height-diameter models for major tree species of Ontario's boreal forests. Northern Journal of Applied Forestry 18: 87-94. [online] URL: http://www.ingentaconnect.com/ content/saf/njaf/2001/00000018/00000003/arto 0004

Zhang L, Bi H, Cheng P, Davis CJ (2004). Modeling spatial variation in tree diameter-height relationships. Forest Ecology and Management 189: 317-329. - doi: 10.1016/j.foreco.2003.09.004

\section{Supplementary Material}

Fig. S1 - Residual distribution (\%) obtained by fitting the modified models for Eucalyptus urophylla $\times$ Eucalyptus grandis (a), Mimosa scabrella (b), Parapiptadenia rigida and Peltophorum dubium (c) and Schizolobium parahybae (d) in order to describe the height growth depending on tree age and climatic factors.

Tab. S1 - Height models tested for Eucalyptus urophylla x Eucalyptus grandis, Mimosa scabrella,Parapiptadenia rigida, Peltophorum dubium and Schizolobium parahybae in Rio Grande do Sul State, Brazil.

Tab. S2 - Biological models of tree height growth modified by the inclusion of climatic factors.

Link: Elli_2189@supploo1.pdf 